\title{
Pelatihan Pengenalan dan Pemanfaatan Media Sosial Untuk Meningkatkan Penjualan Hasil Hidroponik Karang Taruna dan Warga RW 03 Desa Sumber Jaya, Kecamatan Tambun Selatan, Kabupaten Bekasi
}

\author{
Ana Ramadhayanti ${ }^{1}$, Iwan Asmadi' ${ }^{2}$, Zahra ${ }^{3}$, Yulianah ${ }^{4}$ \\ 1,2,3,4 Universitas Bina Sarana Informatika, Jakarta \\ Email: ana.rdx@bsi.ac.id
}

\begin{abstract}
Abstrak
Era digitalisasi saat ini dikenal dengan era digital 4.0. Dikatakan era digital karena begitu masifnya penggunaan internet dimasyarakat. Tetapi sayangnya tidak sedikit masyarakat dapat melihat peluang penggunaan jasa internet adalah potensi pasar untuk memasarkan produk dan jasa yang mereka hasilkan. Maka kami dari TIM Fakultas Ekonomi Universitas Bina Sarana Informatika melakukan kegiatan Pengabdian Masyarakat berupa Pelatihan Pengenalan dan Pemanfaatan Media Sosial Untuk Meningkatkan Penjualan Hasil Hidroponik Karang Taruna dan Warga RW 03 Desa Sumber Jaya, Kecamatan Tambun Selatan, Kabupaten Bekasi dengan tujuan untuk mendorong dan meningkatkan kemampuan para pemuda Karang Taruna dan warga Desa Sumber Jaya yang saat ini telah dapat memproduksi sayuran hidroponik, sehingga dengan demikian dapat mengembangkan bisnisnya dengan meningkatkan penjualan melalui media sosial. Sejak adanya wabah Covid-19, yang ditindak lanjuti dengan PSBB dan PPKM telah memberikan dampak para pedagang dan pengusaha dalam meningkatkan penjualan produknya, begitu pula dengan hasil pertanian hidroponik yang di rintis oleh karang taruna dan warga RW 03 Desa Sumber Jaya, Kecamatan Tambun Selatan, Kabupaten Bekasi. Hasil pelatihan ini diharapkan dapat membuka wawasan dan pengetahuan para karang taruna dan warga desa sumber jaya dalam memanfaatkan media sosial dalam meningkatkan penjualan hasil pertanian hidroponik yang mereka kelola.
\end{abstract}

Kata Kunci: Media Sosial, Peningkatan Penjualan, Hidroponik, E-Commerce.

\section{Abstract}

The current era of digitization is known as the digital era 4.0. It is said that the digital era is due to the massive use of the internet in the community. But unfortunately not a few people can see the opportunity to use internet services is a potential market to market the products and services they produce. So we from the TEAM of the Faculty of Economics, University of Bina Sarana Informatika, carried out Community Service activities in the form of Training on Introduction and Utilization of Social Media to Increase Sales of Hydroponic Products for Youth and Youth RW 03 Sumber Jaya Village, Tambun Selatan District, Bekasi Regency with the aim of encouraging and improving the abilities of the Karang Taruna youth and residents of Sumber Jaya Village who are now able to produce hydroponic vegetables, so that they can develop their business by increasing sales through social media. Since the Covid-19 outbreak, which was followed up with PSBB and PPKM, it has had an impact on traders and entrepreneurs in increasing their product sales, as well as hydroponic agricultural products pioneered by youth organizations and residents of RW 03 Sumber Jaya Village, Tambun Selatan District, Bekasi Regency. The results of this training are expected to open up the insight and knowledge of youth organizations and residents of Sumber Jaya Village in utilizing social media to increase sales of hydroponic agricultural products they manage.

Keywords: Social Media, Increase Sales, Hydroponics, E-Commerce.

\section{A. PENDAHULUAN}

Saat ini kita memasuki era digital di mana masyarakat luas semakin canggih dalam penggunaan internet. Banyaknya masyarakat saat ini memanfaatkan internet untuk memenuhi segala kebutuhan serta aktivitas (Komninos et al., 2013). Masyarakat bisa mendapatkan informasi atau segala kebutuhannya dengan mengakses jaringan internet yang ada di masingmasing teknologi seperti smartphone, laptop, televisi ataupun teknologi lainnya (Alia \& Irwansyah, 2018). Hasil dari data Survei menurut asosiasi penyelenggara jasa internet atau APJII mengungkapkan bahwa pengguna internet di Indonesia pada periode 2019-kuartal 
II/2020 sebesar 196,7 juta jiwa (Azizah et al., n.d.). Sebagian besar pengguna internet tersebut adalah berselancar di media sosial dengan berbagai macam platform di dalamnya ada yang dinamakan market place, inilah yang banyak dimanfaatkan pengguna media sosial yang memasarkan, produk atau mencari barang yang dinginkan. Media sosial juga diargumentasikan sebagai media yang tepat bagi pemasaran karena kemudahan akses (Rahayu \& Syam, 2021). "Media sosial adalah salah satu cara yang digunakan untuk berhubungan satu sama lain" (Toivonen et al., 2019).

Dengan penggunaan media sosial baik melalui blog, sosial networking, Facebook, dan Instagram merupakan langkah strategis dalam memasarkan hasil produk. Selain dapat mengurangi biaya promosi, media sosial juga memiliki jangkauan yang lebih luas dan mudah diakses dalam mempromosikan produknya dibandingkan dengan memasarkan secara konvensional (Lin et al., 2018). Sosial media, sesuai namanya merupakan media yang memungkinkan penggunanya untuk saling bersosialisasi dan berinteraksi, berbagi informasi maupun menjalin kerjasama. Media Sosial adalah sebuah media online, dengan para penggunanya bisa dengan mudah berpartisipasi, berbagi, dan menciptakan isi meliputi blog, jejaring sosial, Wiki, forum dan dunia virtual (Alaby, 2020).

Oleh karena itu pada kegiatan pengabdian masyarakat kali ini, kami berusaha untuk memberikan pelatihan mengenai pengenalan media sosial secara online. Dengan tujuan, agar kegiatan ini mampu memberikan tambahan pengetahuan sekaligus solusi bagi mereka yang sedang meningkatkan penjualannya dan berkembang dan dapat memanfaatkan kemajuan teknologi digital untuk kemajuan organisasinya.

\section{B. TINJAUAN PUSTAKA}

\section{Media Sosial Untuk Meningkatkan Brand}

Media sosial memungkinkan untuk seseorang dapat berinteraksi, bekerja sama atau sekedar berkomunikasi dengan orang lain melalui jalur virtual. Jalur komunikasi ini dilaksanakan melalui media internet sehingga kemudian seseorang dapat merepresentasikan dirinya sehingga tidak lagi terbatas oleh jarak (Shen et al., 2019). Melalui buku yang di tulisnya, Nasrullah menjelaskan terdapat adanya enam kategori besar yang membagi-bagi jenis media sosial. Kategori tersebut antara lain adalah Sosial Networking, Blog, Microblogging, Media sharing, Sosial Bookmarking, dan Wiki (Muslikhin et al., 2021).

Dalam upaya untuk dapat meningkatkan suatu brand atau image, maka sering kali penggunaan Sosial Networking lebih dominan digunakan. Hal ini dikarenakan sifatnya berfungsi untuk berinteraksi satu sama lain, sehingga kemudian memudahkan seseorang untuk mengenalkan suatu produk atau brand yang ingin disebarluaskan kepada orang-orang (Edney et al., 2020).

Contoh dari media sosial sebagai wadah untuk meningkatkan brand adalah Facebook dan juga Instagram. Kedua platform ini sangat memudahkan seseorang untuk memasarkan produk milik mereka, sehingga kemudian dapat dilihat dengan mudah oleh orang lain (Liao et al., 2021). Platform Instagram contohnya, di mana platform ini merupakan media sosial yang khusus berisikan foto-foto penggunanya. Melalui penggunaan foto ini, maka seseorang dapat memberikan gambar mengenai tampilan produknya sehingga dapat lebih jelas diketahui oleh orang-orang yang akan menjadi kliennya (Haenlein et al., 2020). Kemudian sistem caption akan memberikan keleluasaan untuk dapat memberikan deskripsi yang dibutuhkan. Terakhir, adanya sistem hastag (\#) akan memudahkan seseorang untuk dapat mengelompokkan jenisjenis produk yang dimilikinya, sehingga kemudian hal ini memudahkan produk yang ada dapat terlihat lebih jelas dan lebih sering (Bailey et al., 2021). Melalui berbagai fitur yang disediakan oleh sistem Instagram, hal ini menunjukkan bahwa media sosial merupakan tempat yang cocok untuk dapat mengenalkan suatu produk tertentu (Pilgrim \& Bohnet-Joschko, 2019). 


\section{Tanaman Hidroponik}

Hidroponik merupakan suatu metode untuk menanam tumbuhan tanpa menggunakan media berupa tanah. Jika diartikan secara harfiah, hidroponik merupakan penanaman yang dilakukan di dalam air yang telah dicampurkan dengan campuran hara (Maluin et al., 2021). Agar dapat menjadi penopang pertumbuhan tanaman, sering kali metode hidroponik dilakukan dengan menggunakan media tanaman yang lain juga (Fischer et al., 2021).

Metode hidroponik dapat dianggap sebagai suatu media yang efektif. Hal ini dapat dikatakan karena tanaman yang dapat tumbuh dengan kondisi optimal akan menghasilkan potensi produksi yang maksimal (Tunio et al., 2020). Potensi maksimal ini dapat dicapai sebagai akibat dari akar tanaman yang dapat tumbuh secara maksimal tanpa terhalangi oleh kerasnya tanah. Akar yang dapat tumbuh secara maksimal juga kemudian akan mengakibatkan pertumbuhan tunas yang maksimal (Correa et al., 2019). Hal-hal ini kemudian dapat menyebabkan produksi yang sifatnya maksimal dibandingkan dengan tanaman yang akarnya dihalangi oleh tanah (Rehman et al., 2021).

Terdapat banyak keuntungan yang dapat diperoleh melalui sistem hidroponik dibandingkan sistem media tanah yang biasa. Keuntungan tersebut antara lain adalah:

a. Efisiensi penggunaan tanah yang lebih baik

b. Tidak bergantungnya tanaman pada kebutuhan tanah

c. Hilangnya risiko penurunan kualitas sebagai akibat dari penanaman yang dilakukan terus menerus dan mengurangi kualitas tanah

d. Produksi yang sifatnya lebih bersih dan lebih tinggi, baik dari sisi kualitas ataupun kuantitas (Kopittke et al., 2019)

e. Efisiensi terhadap penggunaan pupu dan air

f. Tanaman akan memiliki periode yang jauh lebih cepat dan pendek

g. Penyakit dan hama yang muncul akan lebih mudah dikendalikan dibandingkan periode menggunakan media tanah (Yatoo et al., 2021)

Walaupun memiliki berbagai kelebihan, namun terdapat adanya kekurangan yang dimiliki oleh media hidroponik dibandingkan dengan menggunakan metode tanah yang biasa. Adapun kekurangan tersebut antara lain adalah:

a. Tingginya biaya yang dibutuhkan untuk menerapkan metode hidroponik (Richa et al., 2020).

b. Serangan yang diakibatkan oleh patogen dalam sistem nutrisi disirkulasi akan lebih cepat menyebar kepada tanaman-tanaman lainnya yang masih berada dalam sirkulasi yang sama.

c. Dalam kultur yang sifatnya substrat, maka kapasitas untuk dapat memegang air jumlahnya akan lebih sedikit dibandingkan dengan media tanah, sehingga hal ini dapat menyebabkan tanaman menjadi cepat layu dan stres yang sifatnya lebih serius (Ragaveena et al., 2021).

\section{METODE}

Metode merupakan suatu sistem untuk mencapai tujuan tertentu (Sugiyono, 2016) Pelaksanaan program pengabdian kepada masyarakat ini dilakukan dengan menggunakan metode parsitipatif, penyuluhan, pendampingan dan pelatihan di lokasi Mitra Desa Sumber Jaya, Tabun Selatan, namun sebelum melakukan pengabdian ini kami tim pengabdian masyarakat yang terdiri dari 4 dosen dan 3 mahasiswa melakukan kerja sama dengan karang taruna RW 03 Desa Sumber Jaya, Kecamatan Tambun Selatan, Kabupaten Bekasi. Dikarenakan adanya kebijakan Pemberlakuan Pembatasan Kegiatan Masyarakat (PPKM) dan himbauan untuk Physical Distancing pengabdian masyarakat Fakultas Ekonomi Universitas Bina Sarana Informatika tanggal 2 Oktober 2021 mulai pukul 08.00-12.00 bertempat di Balai Ruang Sekretariat, RT 03 RW 03 Desa Sumber Jaya, Kecamatan Tambun Sekatan, Kabupaten 
Bekasi, dan sebagian dilakukan daring (dalam jaringan) dengan menggunakan aplikasi Zoom Meeting. Tahapan pertama yang kita lakukan pada saat pelatihan ini yaitu pembukaan yang disampaikan oleh ketua Pelaksana Pengabdian masyarakat ibu Ana Ramadhayanti, S.I.Kom., MM. dan menyampaikan strategi dalam mempromosikan produk dengan memanfaatkan media sosial dengan efektif dan efisien. Tahapan kedua pemberian materi tentang pengenalan dan pemanfaatan media sosial untuk meningkatkan hasil penjualan hidroponik yang disampaikan oleh Ibu Zahra, S.Pd., MM. Tahap ketiga memberikan kuesioner kepada peserta, mengenai tanggapan mereka atas kegiatan pengabdian masyarakat ini dan juga feedback atas kegiatan masyarakat ini.

\section{HASIL DAN PEMBAHASAN}

\section{Tahapan Pemberian Materi}

Karena terdapat adanya himbauan untuk melakukan physical distancing, sebagian pelatihan ini dilakukan secara online melalui aplikasi Zoom Meeting. Pelatihan ini terbagi menjadi tiga tahap, yaitu tahap pertama, tahap kedua dan tahap ketiga. Proses tahapan tersebut dapat dilihat sesuai gambar di bawah:

\begin{tabular}{|c|c|c|}
\hline Tahap Pertama & ahap Kedua & ahap Ketiga \\
\hline $\begin{array}{l}\text { - Pembukaan } \\
\text { - Penyampaian } \\
\text { promosi } \\
\text { dalam } \\
\text { promosi } \\
\text { produk } \\
\text { - Pemanfaatan } \\
\text { media sosial } \\
\text { demi efisiensi } \\
\text { dan } \\
\text { efektivitas }\end{array}$ & $\begin{array}{l}\text { - Pemberian } \\
\text { materi } \\
\text { mengenai } \\
\text { manfaat } \\
\text { media sosial } \\
\text { - Penggunaan } \\
\text { media sosial } \\
\text { untuk } \\
\text { meningkatkan } \\
\text { hasil } \\
\text { penjualan }\end{array}$ & $\begin{array}{l}\text { - Pemberikan } \\
\text { kuesioner } \\
\text { mengenai } \\
\text { pengabdian } \\
\text { masyarakat } \\
\text { - Penerimaan } \\
\text { feedback atas } \\
\text { kegiatan yang } \\
\text { dilaksanakan }\end{array}$ \\
\hline
\end{tabular}

Gambar 1. Tahapan Kegiatan Pengabdian Masyarakat

a. Tahap Pertama

Tahap ini diawali dengan melaksanakan diskusi serta kerja sama antara Karang Taruna dan warga RW 03 dengan pihak tim pengabdian masyarakat. Selanjutnya pihak Ketua Pelaksana akan memberikan strategi-strategi awal mengenai bagaimana cara melaksanakan promosi-promosi produk yang dimiliki oleh Karang Taruna dan warga RW 03, dalam hal ini produk hasil hidroponik, melalui media sosial. Kegiatan promosi melalui media sosial ini akan ditekankan kepada sifatnya yang dianggap jauh lebih efektif dan efisien dibandingkan melalui promosi jalur biasa.

Tahapan awal ini dilaksanakan agar para peserta dapat memahami materi selanjutnya yang akan disampaikan, sehingga kemudian para peserta akan merasa antusias dalam menerima materi yang akan diberikan. Tahap pertama akan dibantu oleh berbagai alat dan bahan lainnya, seperti buku pedoman digital pemasaran, hingga contoh-contoh pemasaran akun media sosial yang telah melakukan pemasaran melalui jalur digital.

b. Tahap Kedua

Dalam tahap kedua ini pemberian materi mengenai pengenalan media sosial kepada Karang Taruna dan masyarakat dari RW 03 akan diberikan. Setelah adanya pengenalan, maka berikutnya adalah menjelaskan bagaimana cara memanfaatkan media sosial 
untuk dapat meningkatkan hasil penjualan dari tanaman hidroponik. Hal ini dikarenakan walaupun telah mengenal media sosial, namun media sosial ini perlu dimanfaatkan dengan baik dan benar agar dapat meningkatkan hasil penjualan tanaman hidroponik.

Materi ini disampaikan melalui penjelasan tingkat penggunaan teknologi dalam melakukan penjualan atau perkembangan bisnis. Setidaknya terdapat 4 tingkatan dalam hal ini, yaitu tingkat bisnis offline, tingkat bisnis online dasar, tingkat bisnis online menengah, dan tingkat bisnis online lanjutan/tinggi (Mariani et al., 2018. Adapun status dari Karang Taruna dan warga RW 03 masih dianggap berada di tingkat bisnis offline, sehingga kemudian hal ini perlu diubah dan di tingkatkan menjadi digital marketing yang berbasis online. Tentunya perubahan ini tidak akan serta merta mengubah tingkat perkembangan bisnis Karang Taruna dan warga RW 03 menjadi tingkat bisnis online lanjutan. Namun setidaknya melalui penjualan berbasis online, maka perkembangan bisnis yang ada akan naik tingkat menjadi lebih baik. Perubahan ini dapat diawali dengan menentukan tujuan dari bisnis yang akan dilaksanakan, menciptakan brand sendiri hingga menarik calon pelanggan baru melalui pemanfaatan media online seperti Facebook dan Instagram.

Kemudian dalam pelatihan yang diberikan para peserta juga perlu diperkenalkan dengan pembuatan e-commerce. Pembuatan e-commerce ini dilakukan karena akan sangat memudahkan pelanggan dalam membeli produk hidroponik yang di jual. Melalui e-commerce, pelanggan tinggal masuk ke dalam website yang ditentukan, memilih barang yang ingin dibeli, lalu membayar barang tersebut, sehingga kemudian barang yang diinginkan akan sampai di depan pintu rumah. Semua hal ini dapat dilakukan dari rumah saja, sehingga kemudian kehadiran e-commerce akan sangat memudahkan pelanggan dalam membeli barang yang dibutuhkan.

c. Tahap terakhir

Tahap terakhir dalam pelatihan ini berupa pemberian kuesioner kepada semua peserta pelatihan. Kuesioner ini berisi tanggapan para peserta mengenai bentuk pelatihan yang diberikan, baik dari materi yang disampaikan, ataupun hal-hal lainnya yang berkenaan dengan kegiatan pelatihan pemanfaatan media sosial ini. Tahap ini kemudian diakhiri dengan penerimaan feedback dari para peserta mengenai hasil pelatihan yang telah dilaksanakan.

\section{Hasil Pelatihan}

a. Sosialisasi Digital Marketing

Pelaksanaan pelatihan ini diharapkan dapat memberikan pemahaman kepada Karang Taruna dan warga RW 03 mengenai penggunaan sosial media, khususnya digital marketing dan e-commerce. Kegiatan sosialisasi ini perlu diperhatikan secara antusias oleh peserta, agar kemudian mereka dapat menyimak materi dengan baik. Setelah pemberian materi dilaksanakan, maka selanjutnya adalah melakukan diskusi dengan para peserta mengenai materi yang baru saja disampaikan. Hal ini untuk melihat tingkat antusiasme peserta dalam penyampaian materi tadi. Jika peserta melakukan diskusi secara aktif, maka dapat dikatakan bahwa peserta telah menyimak materi dengan sangat antusias.

b. Pelatihan dan pendampingan terhadap digital marketing

Ketika memberikan materi, pemateri akan menunjukkan bagaimana peserta dapat menambah jumlah pelanggan atau setidaknya peminta produk hidroponik dengan menggunakan media sosial. Hal ini dapat dilakukan dengan menambah jumlah teman atau pengikut yang melihat kita di media sosial, cara menarik orang untuk tertarik dengan produk yang akan peserta jual, cara mengirimkan produk ke konsumen jika 
mereka menggunakan e-commerce, hingga cara melakukan packaging agar produk tampak berkesan bagus dan menarik.

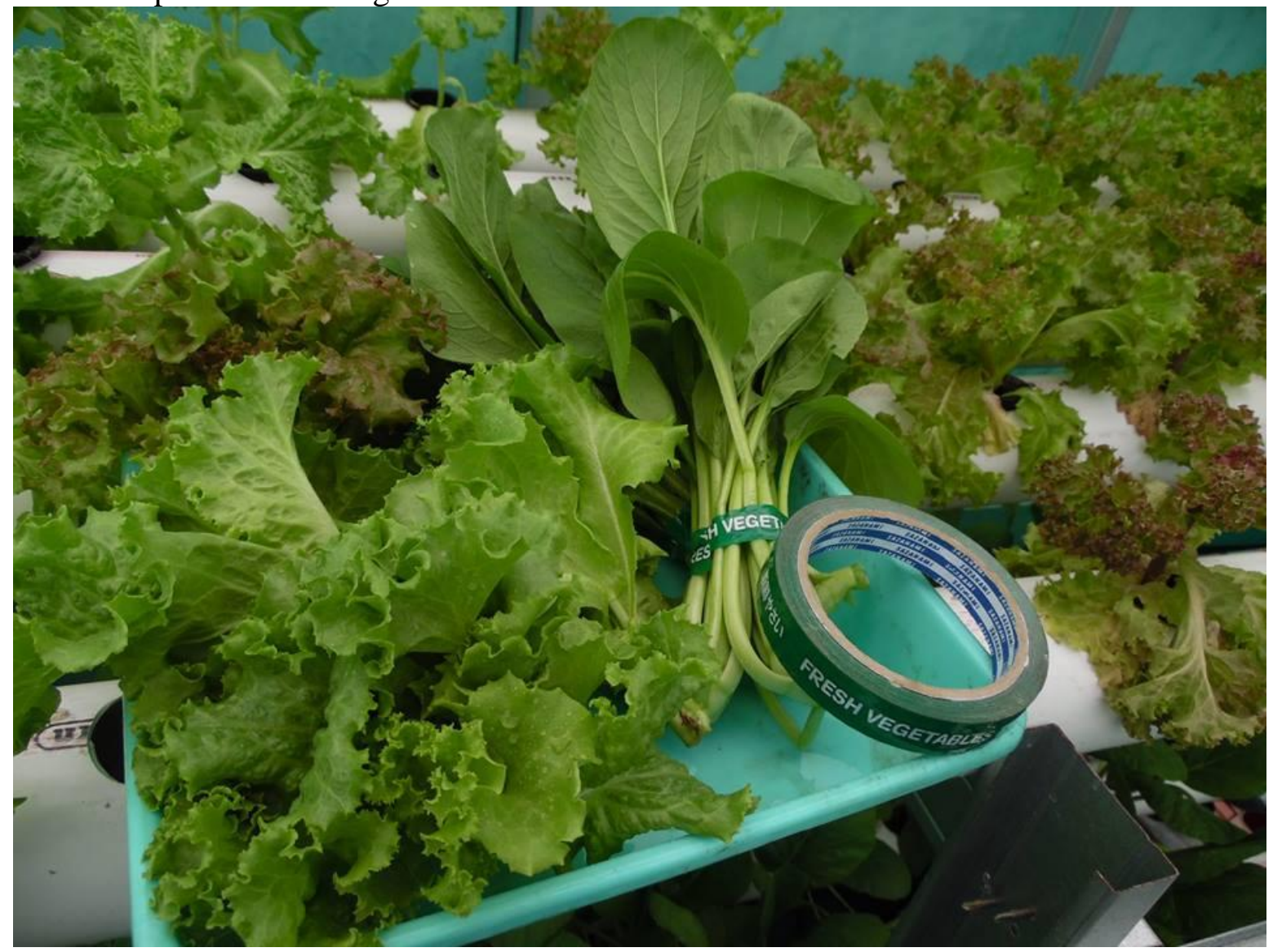

Gambar 2. Packaging Ramah Lingkungan

Instagram

Q Cari

$\widehat{\Omega}$
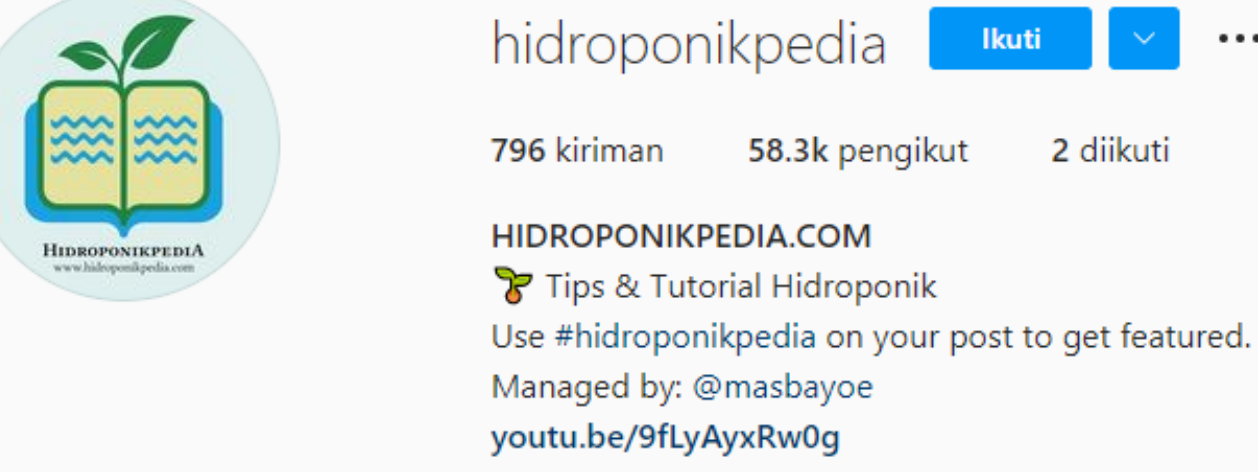

Diikuti oleh maswid2021, adlhanjean, dwitalia_dessy, + 1 lainnya

\section{Gambar 3. Contoh Pemanfaatan Instagram Untuk Menjual Produk Hidroponik}

Melalui pemberian materi ini, diharapkan peserta dapat segera melaksanakan pembuatan media sosial untuk melakukan penjualan. Setidaknya sekitar $70 \%$ lebih diharapkan untuk dapat memanfaatkan media sosial dengan baik. 


\begin{tabular}{|c|l|l|}
\hline \multicolumn{4}{c}{ Tabel 1. Harapan Evaluasi Pengabdian Masyarakat } \\
\hline No. & Sebelum Pelatihan Hidroponik & \multicolumn{1}{c|}{ Setelah Pelatihan Hidroponik } \\
\hline 1 & $\begin{array}{l}\text { Tidak atau kurangnya pengetahuan } \\
\text { dalam melaksanakan pemasaran } \\
\text { secara online }\end{array}$ & $\begin{array}{l}\text { Karang Taruna dan Warga RW 03 sadar dan } \\
\text { mengetahui pentingnya media Online untuk } \\
\text { melakukan pemasaran }\end{array}$ \\
\hline 2 & $\begin{array}{l}\text { Tidak dapat menggunakan media } \\
\text { sosial untuk melakukan pemasaran } \\
\text { terhadap tanaman hidroponik }\end{array}$ & $\begin{array}{l}\text { Karang Taruna dan Warga RW 03 memiliki } \\
\text { pemahaman mengenai pengoperasian media } \\
\text { sosial untuk menjalankan pemasaran produk } \\
\text { hidroponik }\end{array}$ \\
\hline 3 & $\begin{array}{l}\text { Tidak adanya pengetahuan } \\
\text { mengenai cara melakukan } \\
\text { packaging terhadap produk-produk } \\
\text { hidroponik }\end{array}$ & $\begin{array}{l}\text { Karang Taruna dan Warga RW 03 dapat } \\
\text { melakukan packaging terhadap hasil produk- } \\
\text { produk hidroponik mereka }\end{array}$ \\
\hline
\end{tabular}

\section{E. KESIMPULAN}

Kegiatan pengabdian masyarakat dalam bentuk pelatihan terhadap pemasaran tanaman hidroponik di RW 03 Desa Sumber Jaya, Kecamatan Tambun Sekatan, Kabupaten Bekasi diharapkan dapat memiliki hasil yang baik dan sesuai dengan tujuan awal yang diinginkan. Melalui pelatihan ini, Karang Taruna dan warga RW 03 Desa Sumber Jaya, Kecamatan Tambun Sekatan, Kabupaten Bekasi dapat mengoperasikan media sosial dengan lebih baik dalam meningkatkan hasil penjualan produk hidroponik kepada calon pelanggan baru. Hasil ini termasuk di dalamnya penggunaan media sosial, pemanfaatan e-commerce, hingga melakukan packaging agar kemasan produk hidroponik yang akan di jual tampak menarik. Tujuan akhir dari pelatihan ini dilaksanakan agar kemudian para warga dari desa RW 03 Desa Sumber Jaya, Kecamatan Tambun Sekatan, Kabupaten Bekasi dapat memiliki penghasilan tambahan yang dapat membantu hidup mereka sehari-harinya.

\section{REFERENSI}

Alaby, M. A. (2020). Media sosial whatsapp sebagai media pembelajaran jarak jauh mata kuliah ilmu sosial budaya dasar (ISBD). Ganaya: Jurnal Ilmu Sosial dan Humaniora, 3(2), 273-289.

Alia, T., \& Irwansyah, I. (2018). Pendampingan orang tua pada anak usia dini dalam penggunaan teknologi digital [parent mentoring of young children in the use of digital technology]. Polyglot: Jurnal Ilmiah, 14(1), 65-78.

Azizah, N., Noselina, M. Y. R., Hasanah, R. A., \& Nilasari, I. The Effect of Security and User Experience to Repurchase Intention of E-Commerce Users: Evidence from TokopediaIndonesia. Turkish Journal of Physiotherapy and Rehabilitation, 32, 3.

Bailey, K. A., Rice, C., Gualtieri, M., \& Gillett, J. (2021). Is\# YogaForEveryone? The idealised flexible bodymind in Instagram yoga posts. Qualitative Research in Sport, Exercise and Health, 1-16.

Correa, J., Postma, J. A., Watt, M., \& Wojciechowski, T. (2019). Soil compaction and the architectural plasticity of root systems. Journal of experimental botany, 70(21), 60196034.

Edney, S. M., Olds, T. S., Ryan, J. C., Vandelanotte, C., Plotnikoff, R. C., Curtis, R. G., \& Maher, C. A. (2020). A social networking and gamified app to increase physical activity: cluster RCT. American journal of preventive medicine, 58(2), e51-e62.

Fischer, H., Romano, N., Jones, J., Howe, J., Renukdas, N., \& Sinha, A. K. (2021). Comparing water quality/bacterial composition and productivity of largemouth bass Micropterus 
salmoides juveniles in a recirculating aquaculture system versus aquaponics as well as plant growth/mineral composition with or without media. Aquaculture, 538, 736554.

Haenlein, M., Anadol, E., Farnsworth, T., Hugo, H., Hunichen, J., \& Welte, D. (2020). Navigating the New Era of Influencer Marketing: How to be Successful on Instagram, TikTok, \& Co. California Management Review, 63(1), 5-25.

Komninos, N., Pallot, M., \& Schaffers, H. (2013). Special issue on smart cities and the future internet in Europe. Journal of the knowledge economy, 4(2), 119-134.

Kopittke, P. M., Menzies, N. W., Wang, P., McKenna, B. A., \& Lombi, E. (2019). Soil and the intensification of agriculture for global food security. Environment international, 132, 105078.

Liao, S. H., Widowati, R., \& Hsieh, Y. C. (2021). Investigating online social media users' behaviors for social commerce recommendations. Technology in Society, 66, 101655.

Lin, H. C., Bruning, P. F., \& Swarna, H. (2018). Using online opinion leaders to promote the hedonic and utilitarian value of products and services. Business horizons, 61(3), 431442.

Maluin, F. N., Hussein, M. Z., Nik Ibrahim, N. N. L., Wayayok, A., \& Hashim, N. (2021). Some Emerging Opportunities of Nanotechnology Development for Soilless and Microgreen Farming. Agronomy, 11(6), 1213.

Mariani, M., Baggio, R., Fuchs, M., \& Höepken, W. (2018). Business intelligence and big data in hospitality and tourism: a systematic literature review. International Journal of Contemporary Hospitality Management.

Muslikhin, M., Mulyana, D., Hidayat, D. R., \& Utari, P. (2021). The Commodification, Spatialization and Structuration of Social Media in the Indonesian Cyber Media News. Media and Communication, 9(2), 110-118.

Pilgrim, K., \& Bohnet-Joschko, S. (2019). Selling health and happiness how influencers communicate on Instagram about dieting and exercise: Mixed methods research. BMC Public Health, 19(1), 1-9.

Ragaveena, S., Shirly Edward, A., \& Surendran, U. (2021). Smart controlled environment agriculture methods: a holistic review. Reviews in Environmental Science and Bio/Technology, 20(4), 887-913.

Rahayu, E. L. B., \& Syam, N. (2021). Digitalisasi Aktivitas Jual Beli di Masyarakat: Perspektif Teori Perubahan Sosial. Ganaya: Jurnal Ilmu Sosial Dan Humaniora, 4(2), 672-685.

Rehman, A. U., Nazir, S., Irshad, R., Tahir, K., ur Rehman, K., Islam, R. U., \& Wahab, Z. (2021). Toxicity of heavy metals in plants and animals and their uptake by magnetic iron oxide nanoparticles. Journal of Molecular Liquids, 321, 114455.

Richa, A., Touil, S., Fizir, M., \& Martinez, V. (2020). Recent advances and perspectives in the treatment of hydroponic wastewater: a review. Reviews in Environmental Science and Bio/Technology, 1-22.

Shen, C. W., Chen, M., \& Wang, C. C. (2019). Analyzing the trend of O2O commerce by bilingual text mining on social media. Computers in Human Behavior, 101, 474-483.

Sugiyono, P. (2016). Metode Penelitian (Pendekatan Kuantitatif, Kualitatif, dan R\&D). Bandung: Alfabeta.

Toivonen, T., Heikinheimo, V., Fink, C., Hausmann, A., Hiippala, T., Järv, O., ... \& Di Minin, E. (2019). Social media data for conservation science: A methodological overview. Biological Conservation, 233, 298-315.

Tunio, M. H., Gao, J., Shaikh, S. A., Lakhiar, I. A., Qureshi, W. A., Solangi, K. A., \& Chandio, F. A. (2020). Potato production in aeroponics: An emerging food growing system in sustainable agriculture forfood security. Chilean journal of agricultural research, 80(1), 118-132. 
Yatoo, A. M., Ali, M. N., Baba, Z. A., \& Hassan, B. (2021). Sustainable management of diseases and pests in crops by vermicompost and vermicompost tea. A review. Agronomy for Sustainable Development, 41(1), 1-26. 